\title{
LEGISLAC̣ÃO ADEQUADA PARA A ENFERMAGEM: UMA NECESSIDADE A SER CONQUISTADA
}

No dia 08 de Junho de 1987 entrou em vigor no Brasil uma nova legislação do exercício profissional da enfermagem. É a lei n? 7.498 que substitui a lei n? 2.604 de 1955.

Foram quase 10 anos de luta da enfermagem brasileira para obtenção da atualização da legislação do exercício profissional. E, uma avaliação mais rigorosa mostra que o resultado deste processo está muito longe do desejado e que uma legislação adequada para a enfermagem ainda é uma necessidade a ser conquistada.

O trabalho da enfermagem, apesar das suas características especiais, amplamente reconhecidas, continua sem nenhuma proteção legal. Os riscos permanentes a que estão submetidos os profissionais de enfermagem e a exigência emocional, física e técnica para um trabalho diuturno de 24 horas por dia, 7 dias por semana e 365 dias por ano de cuidados com a saúde e a vida das pessoas não estão compensadas com jornadas adequadas, salários condignos e aposentadoria proporcional.

Esta é uma das razões mais importantes da crise atual vivida pela profissão. A instabilidade, a insegurança, a falta de confiança no futuro e a desvalorização do trabalho da enfermagem, além da deterioração da assistência prestada à população, estão levando a uma grande insatisfação e forte tendência à evasão profissional.

A lei do exercício profissional, agora vigente, não contempla estas questões. Acabou prevalecendo no Congresso Nacional e nos vetos da Presidência da República os interesses do setor hospitalar, curativo e empresarial, dominante da política de saúde do Brasil.

Porém, a aplicação desta nova lei permite um amplo debate sobre o seu significado e a oportunidade de uma reflexão por toda a enfermagem dos seus problemas e a consciência de que a legislação será sempre a regulamentação de uma situação social e não o contrário. Ou seja, não teremos uma legislação que assegure os direitos da profissão sem antes termos conquistado estes direitos, na prática, pela nossa ação no conjunto da sociedade.

Deste amplo debate, também deve surgir as condições para aplicação imediata dos pontos positivos desta Lei 7.498, especialmente, a participação efetiva da enfermagem nas decisões e gestão do setor saúde, o reconhecimento do técnico e a valorização dos trabalhadores de enfermagem e a conquista da profissionalização de todos os atendentes de enfermagem até o ano 2.000 .

Convidamos a enfermagem para se engajar nesta jornada de reflexão, de luta e, a partir daí,alcançar novos dias para a profissão e uma legislação adequada ao seu peso decisivo no atendimento das necessidades de saúde da população. 